\title{
EFFECT OF DIFFERENT POZZOLANA ON HARDENING PROCESS AND PROPERTIES OF HYDRAULIC BINDER BASED ON NATURAL ANHYDRITE
}

\author{
Jadvyga Žvironaitė ${ }^{1}$, Ina Pundiené ${ }^{2}$, Sergejus Gaidučis ${ }^{3}$, Viktor Kizinievič \\ 1, 2,4 Institute of Thermal Insulation, Vilnius Gediminas Technical University, \\ Linkmenu g. 28, LT-08217 Vilnius, Lithuania \\ ${ }^{3}$ Department of Labour Safety and Fire Protection, Vilnius Gediminas Technical University, \\ Sauletekio al. 11, LT-10223 Vilnius, Lithuania \\ E-mails: ${ }^{1} j a d v y g a . z v i r o n a i t e @ v g t u . l t$ (corresponding author); ${ }^{2}$ ina.pundiene@gmail.com; \\ ${ }^{3}$ sergejus.gaiducis@gmail.com; ${ }^{4}$ viktor.kizinievic@termo.vgtu.lt
}

Received 08 Feb. 2012; accepted 04 May 2012

\begin{abstract}
The study deals with peculiarities of hydration and development of hardening structure as well as durability properties pertaining to composite anhydrite cement pozzolana binder (ACP) with different pozzolana $(\mathrm{P})$. The properties of $\mathrm{P}$ have an effect on ACP hydration, structure development and durability properties. This effect is different than that in cement pastes. Investigations were performed with known P: natural opoka (O) and microsilica (MS), also with production waste of mineral wool - cupola dust (CD), which is famous for high fineness and amorphous structure of particles. It was established that the activity of $\mathrm{P}$ compounds contained in $\mathrm{CD}$ was very high making this waste suitable for ACP as a P component. In ACCD samples, one could observe the most intense hydration; and after a longer inductive period, the development of hardening microstructure was more rapid than in ACMS or ACO; furthermore, a remarkably higher strength was reached. The slowest hydration and structure compacting as well as the lowest strength were found in ACMS samples. It shows that the high pozzolanic activity of $\mathrm{P}$ is not the crucial index in evaluation of its effect on ACP properties. Chemical properties of $\mathrm{P}$ have a remarkably greater effect; and in case of $\mathrm{CD}$, it is most likely due to reactive alkaline admixtures.
\end{abstract}

Keywords: natural anhydrite, anhydrite-cement-pozzolana binder, cupola dust, ultrasonic wave velocity tests, durability.

\section{Introduction}

In order to reduce $\mathrm{CO}_{2}$ emissions into the environment, more attention is increasingly given to research of composite hydraulic binder, which may partially replace Portland cement. It is a well known fact the production of Portland cement requires high power input and high $\mathrm{CO}_{2}$ emissions (up to $0.9 \mathrm{t}$ per ton of Portland cement CEM I). Composite anhydrite binder based on unburned natural anhydrite (A) is one of composite binders that require extremely low input of power. Sulphate composite hydraulic binders based on gypsum binder have been long known and largely used (Volženskij et al. 1971). Hemihydrate gypsum (G) is mostly used as a sulphate component, while anhydrite (A) is used less often. Cement, granulated blast-furnace slag and fly ash have been used as hydraulic additives (Yan et al. 1999; Colak 2002; Martinez-Aguilar et al. 2010). First of all, water resistance properties of these binders depend on the content of the hydraulic component, i.e. cement, however, the type of a sulphate component, in particular its morphology, have a significant effect as well. Binders with a sulphate component of dense crystalline structure - e.g. $\alpha$-hemihydrate gypsum or anhydrite - are more resistant to water impact primarily due to lesser water demand and consequently lower porosity of the matrix.
The porosity is one of the most important characteristics determining water resistance of gypsum matrix (Singh, Garg 1996; Sattler 1997). In the case of A, slow hydration process has an influence, which results in long-term compacting and strengthening of hardening structure (Žvironaitè et al. 2010).

Large underground layers of natural anhydrite are available in Lithuania (Grigelis, Kadunas 1994). Mining of anhydrite at Pagiriai deposit (depth of $~ 305 \mathrm{~m}$ ) is expected to start in 2012. This anhydrite is a very pure rock of dense crystalline structure (the content of the main mineral $\mathrm{CaSO}_{4}$ is 93-98\%). Long-term investigations conducted by Lithuanian researchers have demonstrated that this rock could be used for production of unburned anhydrite binder with good strength properties and high degree of whiteness, as well as hydraulic composite anhydrite cement pozzolana (ACP) binders (Lasys, Kadunas 1994; Žvironaite, Kizinievič 2010). The natural pozzolana $(\mathrm{P})$ - opoka - was used as $\mathrm{P}$ component in these investigations.

The possibility to use waste as a $\mathrm{P}$ component for production of ACP binder is no less important. Such waste with pozzolanic properties as fly ash or silica fume is widely used as supplementary component for the production of common cement (EN 197-1:2011) and con- 
cretes. Numerous studies were dedicated to such investigations (Oliveira et al. 2006; Boudchicha et al. 2007). Over the last years, other wastes were investigated as pozzolanic supplementary constituents: ground glass (Shi et al. 2005), matt waste (Bignozi et al. 2009, 2010), municipal solid waste incinerator bottom ash (K. L. Lin, D. F. Lin 2006; Saccani et al. 2005), polishing ceramic sludge (Andreola et al. 2010; Bignozzi, Bonduà 2011) and etc. One of the relatively new types of waste that contains very fine amorphous silica, which could probably be used as a $\mathrm{P}$ component without prior preparation, is waste from production of rock wool, i.e. cupola dust (CD). This waste accumulates in outgoing air filters and is very dispersive with strong sorption properties. There is very little data in the scientific literature related to potential applications of this waste for building products. It was established (Leškevičienè, Nizevičienè 2010) that burning the neutralized phosphogypsum with a $\mathrm{CD}$ additive, the setting of phosphoanhydrite binder quickens and the strength increases, in particular the early one. Investigations (Žvironaite et al. 2011) demonstrated that a CD additive acts on the process of cement hardening and their strength properties, and that the effect is subject to mineral composition and fineness of cement.

The role of $\mathrm{P}$ in GCP composites is to bind the product of cement hydration $-\mathrm{Ca}(\mathrm{OH})_{2}$ - into hydrosilicates and avoid any risk of destruction of hardened material due to formation of ettringite. The content of $\mathrm{P}-$ i.e. $\mathrm{P} / \mathrm{C}$ ratio in the composition - should be at least such as to ensure the full consumption of $\mathrm{Ca}(\mathrm{OH})_{2}$. Excessive content of $\mathrm{P}$ is also undesirable, since it worsens strength and other durability properties, e.g. frost resistance. $\mathrm{P}$ is inert in respect of sulphate component; nevertheless, due to the effect of 'dilution' and "screening" of G (or A) particles, particularly in case of very high fineness of $P$, the hydration process of a sulphate component and hardening structure formation may be slower. On the other hand, the effect of waste P, particularly containing reactive admixtures as well as nanoscale size particles, may be different. It acts on hardening both the cement and sulphate components and thereby - on hardening of their compositions. Tokarev and Yakovlev (2010) established that superdispersed waste with alumina prevailing to their chemical composition cause the intensification of the hydrate and structure formation of the anhydrite binder. Kadri et al. (2010) presented, that both chemical nature as well as fineness of mineral additives are important for the cement hydration process and strength development. Korpa et al. (2008) found, that the particles of nanoscale size accelerate in early hydration reaction of cement by providing large amount of reactive siliceous surface which serves as a site for early C-S-H precipitation. According to Qing et al. (2007), the pozzolanic activity of nano- $\mathrm{SiO}_{2}$ is much greater than that of silica fume. Nano- $-\mathrm{SiO}_{2}$ accelerates the cement hydration process, consumes calcium hydroxide crystals, reduces its size and improves strength properties of hardened cement pastes, the interface structure between aggregate and paste more effectively than silica fume.
In this study, the peculiarities of hardening process and properties of ACP composites with different P component including waste from production of rock woolcupola dust - are investigated. The integrated investigation focused on the change of $\mathrm{OH}^{-}$concentration in liquid phase, hydration kinetics, formation of initial microstructure and durability properties of hardening ACP.

\section{Experimental}

\subsection{Materials}

Ground natural anhydrite (A) and Portland cement CEM I 42.5 R according to EN 197-1 (2011) (C) were used in this work. The content of the main mineral $-\mathrm{CaSO}_{4}-$ in anhydrite was $\sim 94 \%$. The mineral composition of cement clinker was: $\mathrm{C}_{3} \mathrm{~S}-59 \%, \mathrm{C}_{2} \mathrm{~S}-14 \%, \mathrm{C}_{3} \mathrm{~A}-9 \%, \mathrm{C}_{4} \mathrm{AF}-$ $11 \%$. Specific surface area (Blaine) of ground anhydrite was $360 \mathrm{~m}^{2} / \mathrm{kg}$, of cement $-370 \mathrm{~m}^{2} / \mathrm{kg}$.

The following materials were used as pozzolana additives $(\mathrm{P})$ :

- cupola dust (CD). The X-ray diffraction tests showed that cupola dust was dominated by amorphous compounds; it also contained small amounts of crystalline dolomite, halite and sylvine, originated from rock wool raw materials (Fig. 1). From the index of electric conductivity of suspension (Table 1), one could judge about some soluble compounds contained in the dust. The mean diameter of a particle was $14.04 \mu \mathrm{m} .50 \%$ of particles were smaller than $5.59 \mu \mathrm{m}, 8 \%$ of particles were of nanoscale size, i.e. smaller than $100 \mathrm{~nm}$; and $3.9 \%$ were smaller than $70 \mathrm{~nm}$ (Fig. 2);

- granular microsilica RW-Füller (MS) produced by RW Silicium $\mathrm{GmbH}$ with predominant particles of $8 \mu \mathrm{m}$ to $20 \mu \mathrm{m}$. $50 \%$ of particles were smaller than $11.79 \mu \mathrm{m}$. The mean diameter of a particle was $12.24 \mu \mathrm{m}$ (Fig. 2);

- opoka (O). Carbonate opoka from Stoniškiai area (Lithuania) was used. The content of active $\mathrm{SiO}_{2}$ was approximately $51 \%$ and finely dispersed calcium carbonates amounted to approximately $33 \%$. The mean diameter of a particle was $15.18 \mu \mathrm{m} .50 \%$ of particles were smaller than $6.95 \mu \mathrm{m}$ (Fig. 2).

The chemical composition of $\mathrm{P}$ is given in Table 1 .

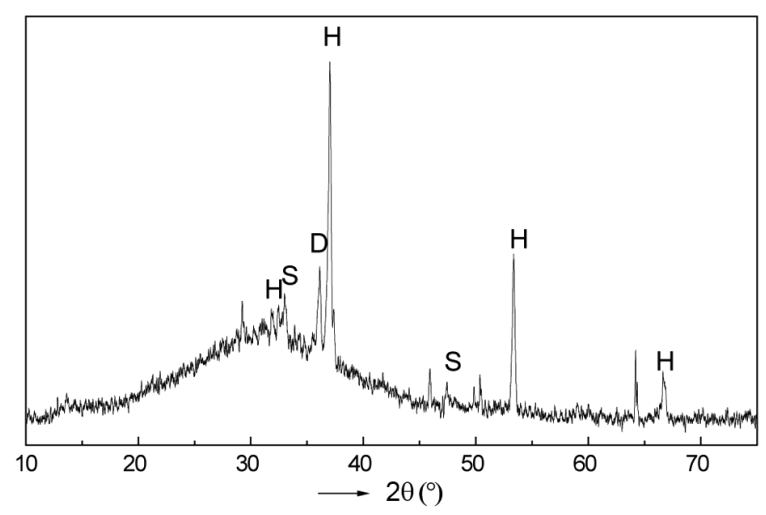

Fig. 1. The X-Ray diffraction pattern of CD: $\mathrm{S}-$ sylvine; $\mathrm{H}$ - halite; D - dolomite 


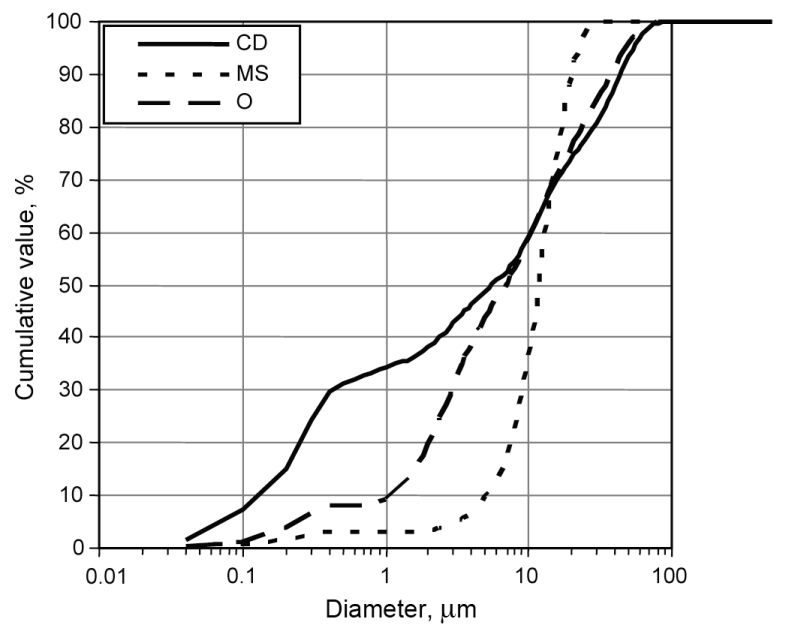

Fig. 2. Particle size distribution of non pre-dispersed $P$

Table 1. Chemical composition (in \%), conductivity and $\mathrm{pH}$ of $\mathrm{P}$

\begin{tabular}{c|c|c|c}
\hline Item & $\mathrm{CD}$ & $\mathrm{MS}$ & $\mathrm{O}$ \\
\hline $\mathrm{SiO}_{2}$ & 49.8 & 96.1 & 66.1 \\
\hline $\mathrm{Al}_{2} \mathrm{O}_{3}$ & 3.4 & 0.2 & 1.8 \\
\hline $\mathrm{Fe}_{2} \mathrm{O}_{3}$ & 7.3 & 0.1 & 0.7 \\
\hline $\mathrm{CaO}$ & 2.5 & 0.3 & 16.3 \\
\hline $\mathrm{MgO}$ & 11.8 & 0.4 & 0.1 \\
\hline $\mathrm{SO}_{3}$ & 0.7 & 0.4 & 0.4 \\
\hline $\mathrm{Na}_{2} \mathrm{O}$ & 5.6 & 1.2 & - \\
\hline $\mathrm{K}_{2} \mathrm{O}$ & 4.6 & 0.1 & 0.2 \\
\hline $\mathrm{Cl}$ & 0.4 & - & - \\
\hline Loss on ignition & 11.4 & 0.4 & 14.3 \\
\hline Conductivity, $\mu \mathrm{S} / \mathrm{cm}$ & 3100 & 400 & 285 \\
\hline $\mathrm{pH}$ & 9.5 & 8.1 & 8.4 \\
\hline
\end{tabular}

\subsection{Test methods}

$\mathrm{P} / \mathrm{C}$ ratio in ACP compositions were determined using the method where the content of available $\mathrm{CaO}$ on the liquid phase of hydrating composites after 5 days should not have exceeded $1.1 \mathrm{~g} / l$ and after 7 days $-0.85 \mathrm{~g} / l$ (Volženskij et al. 1971). ACP suspensions with various $\mathrm{P} / \mathrm{C}$ were conducted at $20^{\circ} \mathrm{C}$ temperature. At the beginning (during $3 \mathrm{~h}$ ) they were constantly shaken and later - once per day. After 5 and 7 days, the suspensions were filtered and $\mathrm{OH}^{-}$ion content was determined by titrating with $0.1 \mathrm{~N}$ $\mathrm{HCl}$. $\mathrm{CaO}$ content was determined by calculating. Values of effective $\mathrm{P} / \mathrm{C}$ that also reflect the pozzolanic activity of different $\mathrm{P}$ in ACP composition were selected using a graphical method.

For investigation of hardening structure development in ACP pastes by measurement ultrasonic wave velocity (UWV) the Schleibinger Geräte $\mathrm{GmbH}$ datalogger with the Pundit 7 ultrasonic pulse indicator was used. Fresh paste was set between two ultrasonic transducers operating at 10 pulses per second and frequency of $54 \mathrm{kHz}$.

To investigate strength and durability properties, ACP samples (cubes $40 \times 40 \times 40 \mathrm{~mm}$ ) were moulded from pastes of uniform plasticity (consistence of $120 \mathrm{~mm}$ according to Suttard viscosimeter). The procedure for mixing of pastes was as follows: $\mathrm{C}$ and $\mathrm{P}$ were mixed in water for $3 \mathrm{~min}$; once A component was added, mixing continued for another $1 \mathrm{~min}$. Samples were held in moulds for one day and then were cured for following 27 days in conditions of $100 \%$ of relative humidity and at $20{ }^{\circ} \mathrm{C}$ temperature. To determine the durability of hardened composites, the samples were divided into five groups cured as follows:

- under the same conditions (H conditions);

- in water at $20^{\circ} \mathrm{C}$, which was changed weekly to imitate flowing water (FW20 conditions), thus allowing for ettringite to form;

- in water at $4{ }^{\circ} \mathrm{C}$, which was changed weekly (FW4 conditions). This method was suggested by Alksnis (1998) to determine the resistance of gypsum cementious composites for thaumasite formation. Minimum testing time of 3 month corresponds to the time of thaumasite synthesis.

- in unchanged water at $20^{\circ} \mathrm{C}$ (NW20 conditions) and $4{ }^{\circ} \mathrm{C}$ (NW4 conditions).

The estimated strength of ACP with different P proportional to equal its density was calculated according to:

$$
f_{\text {estimated }}^{\mathrm{ACP}}=f_{\text {actual }}^{\mathrm{ACP}} \frac{\rho_{\text {equal }}^{2}}{\rho_{\text {actual }}^{2}} \text {, }
$$

where $f_{\text {actual }}^{\mathrm{ACP}}$ is the actual strength of $\mathrm{ACP}$, while $\rho_{\text {equal }}$ and $\rho_{\text {actual }}$ are the equal and actual density of ACP, accordingly.

For investigation of freeze-thaw resistance of hardened ACP, the samples were conditioned by immersion in water for 2 days and then subjected to repeated cycles of freezing and thawing (freezing at a temperature of $-15^{\circ} \mathrm{C}$, thawing in water at a temperature of $+20^{\circ} \mathrm{C}$ ).

Table 2. $\mathrm{OH}^{-}$and available $\mathrm{CaO}$ content in liquid phase of hydrating ACP

\begin{tabular}{|c|c|c|c|c|c|c|}
\hline \multirow{2}{*}{ Type of ACP } & \multirow{2}{*}{$\mathrm{P} / \mathrm{C}$} & \multicolumn{2}{|c|}{$\mathrm{OH}^{-}$content, $\mathrm{g} / l$} & \multicolumn{2}{|c|}{$\mathrm{CaO}$ content, $\mathrm{g} / \mathrm{l}$} & \multirow{2}{*}{ Effective $\mathrm{P} / \mathrm{C}$} \\
\hline & & 5 day & 7 days & 5 day & 7 days & \\
\hline \multirow{3}{*}{$\mathrm{ACO}$} & 0.5 & 0.92 & 0.72 & 1.52 & 1.18 & \multirow{3}{*}{1.0} \\
\hline & 1.0 & 0.64 & 0.49 & 1.06 & 0.81 & \\
\hline & 1.5 & 0.52 & 0.43 & 0.87 & 0.71 & \\
\hline \multirow{3}{*}{ ACMS } & 0.5 & 0.49 & 0.41 & 0.80 & 0.67 & \multirow{3}{*}{0.4} \\
\hline & 1.0 & 0.21 & 0.18 & 0.35 & 0.30 & \\
\hline & 1.5 & 0.09 & 0.07 & 0.15 & 0.12 & \\
\hline \multirow{3}{*}{$\mathrm{ACCD}$} & 0.5 & 0.75 & 0.62 & 1.15 & 0.94 & \multirow{3}{*}{0.6} \\
\hline & 1.0 & 0.58 & 0.38 & 0.75 & 0.58 & \\
\hline & 1.5 & 0.37 & 0.21 & 0.61 & 0.34 & \\
\hline
\end{tabular}


The content of hydrated water (HW) was determined by stopping hydration process by acetone and heating the dried samples at $500{ }^{\circ} \mathrm{C}$.

XRD analyses were carried out using a DRON-7 diffractometer (anticathode - cooper, anode voltage of $30 \mathrm{kV}$ and anode current of $8 \mathrm{~mA}$ ). Particle size distribution was determined using laser particle measuring device Cilas 1090 Liquid (France).

\section{Results and discussion}

\subsection{Selection of effective $P / C$}

The results of selection of the effective $\mathrm{P} / \mathrm{C}$ ratio are given in Table 2. As predicted, the concentration of $\mathrm{OH}^{-}$ ions in ACP suspensions was most effectively decreased by MS, famous for its high pozzolanic activity in cement based systems (Korpa et al. 2008; Qing et al. 2007). CD activity in ACP compositions was lower than that of MS, however, noticeably higher than O. Nonetheless, upon evaluation of the chemical composition of $\mathrm{P}$ given in Table 1 (content of $\mathrm{P}$ compounds, i.e. $\mathrm{SiO}_{2}+\mathrm{Al}_{2} \mathrm{O}_{3}$, in $\mathrm{CD}$ was approximately twice less than in MS, and the actual $\mathrm{P} / \mathrm{C}$ was respectively lower in the composite), one can state that the activity of the P compound contained in $\mathrm{CD}$ was greater yet than that of MS. It is likely that such high activity of the $\mathrm{P}$ compound of $\mathrm{CD}$ was determined by the presence of nanoscale size particles in it (Fig. 2), i.e. nano- $\mathrm{SiO}_{2}$ (Qing et al. 2007).

The compositions of ACP pastes with a constant flow diameter $(120 \pm 5 \mathrm{~mm})$, selected respectively by effective $\mathrm{P} / \mathrm{C}$ (Table 2), are given in Table 3 . One can observe that regardless of lower content in the compositions, the demand of water - i.e. water/solid (W/S) ratio - in case of MS and CD increases. Additions of very fine mineral particles to mixtures, especially of nanoscale size, resulted in the need for high amounts of water in order to keep equal plasticity of mixtures (Senff et al. 2009).

Table 3. Composition of ACP pastes

\begin{tabular}{c|c|c|c|c}
\hline \multirow{2}{*}{$\begin{array}{c}\text { Type of } \\
\text { ACP }\end{array}$} & \multicolumn{3}{|c|}{ Composition, \% mass } & \multirow{2}{*}{ W/S } \\
\cline { 2 - 4 } & $\mathrm{A}$ & $\mathrm{C}$ & $\mathrm{P}$ & \\
\hline ACO & 60 & 20 & 20 & 0.40 \\
\hline ACMS & 72 & 20 & 8 & 0.47 \\
\hline ACCD & 68 & 20 & 12 & 0.44 \\
\hline
\end{tabular}

\subsection{Hydration and hardening structure development of ACP composites}

The data of hydration water (HW) content in hardening ACP composites with different $\mathrm{P}$ are given in Fig. 3. It can be observed that kinetics of hydration of different ACP differs. Furthermore, these differences were not only predetermined by the impact of $\mathrm{P}$ on $\mathrm{C}$ hydration. In ACP composites, the content of the $\mathrm{C}$ component was lower by few times than A (see Table 3); therefore, its hydration effect on the total HW content in ACP composites was less significant. Calculations showed that the total HW content in fully hydrated ACP reached approximately $20-21 \%$ from $(\mathrm{A}+\mathrm{C})$, and the HW content concerning the hydration of cement minerals was lower than
$5 \%$, i.e. lower than one fourth of the total HW. Therefore, the change of the HW content in ACP composites in large part reflected the hydration of A. As one can observe, ACCD paste hydrated the most rapidly and in 24 hours almost half of $(\mathrm{A}+\mathrm{C})$ content was already hydrated. Such rapid hydration was probably predetermined by soluble in particular alkaline - compounds contained in CD. One cannot reject a probability that the presence of nanoscale size particles of $\mathrm{SiO}_{2}$ could have also had an effect, especially on hydration of cement (Korpa et al. 2008; Qing et al. 2007). The hydration process of ACO and ACMS pastes was slower and after $24 \mathrm{hrs,} \mathrm{less} \mathrm{than} \mathrm{one} \mathrm{third} \mathrm{of}$ $(\mathrm{A}+\mathrm{C})$ content was hydrated. While comparing the kinetics of hydration in these two composites, one could observe that after $24 \mathrm{~h}$ the $\mathrm{HW}$ content was slightly higher in ACMS; however, after 7 days, the HW content was already higher in ACO paste and remained such during further periods of hardening. It is likely that the screening effect of very fine MS on hydration of A particles manifested at that point and was unobserved at the beginning because of more intense $\mathrm{C}$ hydration in the ACMS composition. Approximately after 7 days, similar kinetics of hydration settled into shape in all pastes; the HW content continued to gradually increase, however, in ACMS and ACO pastes it remained lower by $2-3 \%$ than in the ACCD paste. Over this period and later, the HW content was increasing practically due to long term A hydration (Žvironaite et al. 2010). The XRD analysis also showed that in the hardened compositions, the A content was gradually decreasing, while that of $\mathrm{G}$ was increasing. In the ACP pastes, which were hardened for 7 months, the XRD analysis showed that A and G peaks were dominating and there were no peaks of destructive minerals (ettringite, thaumasite) (Fig. 4).

For investigation of hydration and microstructure development process in the hardening binder, ultrasonic wave velocity (UWV) methods have recently become more and more popular (Reinhardt, Grosse 2004; Trtnik et al. 2008; Liu et al. 2011; Subramaniam, Wang 2010; Kamada et al. 2005). It is proposed to describe the hydration and hardening process in 3 steps: 1 - when UWV

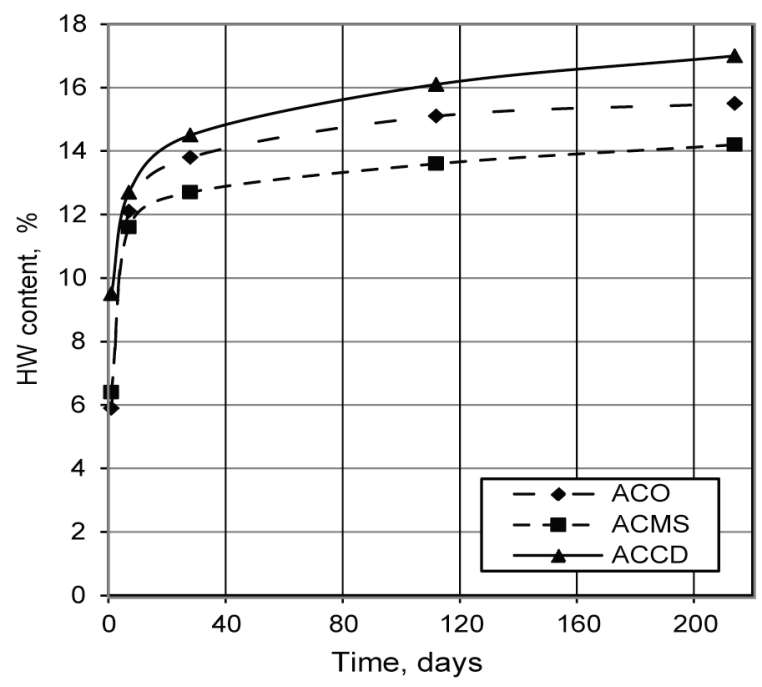

Fig. 3. Variation of hydrated water content in hardening ACP 


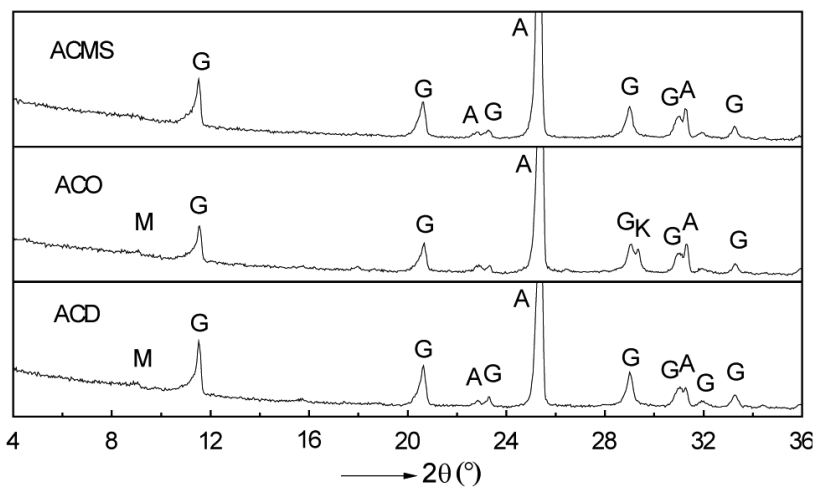

Fig. 4. X-ray diffraction pattern of hardened (for 7 months) ACP pastes: $\mathrm{G}$ - gypsum; $\mathrm{A}$ - anhydrite; $\mathrm{M}$ - calcium monosulphoaluminate; $\mathrm{K}$ - calcite

does not change, i.e. beginning of hydrate formation (induction period, normally ( $3-4 \mathrm{~h}) ; 2-$ when UWV sharply increases, i.e. massive precipitation of hydrates with a progressive transition from amorphous to crystallized forms, the mixture stiffens (quick structure compaction period); 3 -when UWV slowly increases and became stable, then cement skeleton approaches its final stiffness.

The results of UWV measurements in hardening ACP pastes are given in Fig. 5. To the aim of revealing the changing effect of $\mathrm{P}$ in ACP composites, the UWV tests of hardening plain cement $(\mathrm{C})$ and $\mathrm{P}$ modified cement (CP) pastes were performed as well. One can observe that the kinetics of formation of initial structure of $\mathrm{C}, \mathrm{CP}$ and $\mathrm{ACP}$ pastes differed, i.e. the inductive period of ACP pastes was noticeably longer (by 2-3 times versus $\mathrm{CP}$ ) and that the microstructure was compacting slower than $\mathrm{C}$ or $\mathrm{CP}$. The effect of different $\mathrm{P}$ on hardening ACP and CP pastes was also varied. The formation of initial structure in $\mathrm{CP}$ pastes was most effectively stimulated by MS additive (the shortest inductive period and the most rapid increase of UWV values), $\mathrm{O}$ additive also somewhat prolonged the inductive period of $\mathrm{C}$ hardening, however, later the development of microstructure was slightly faster than in the plain cement paste. The $C D$ additive practically had no influence on the inductive period, but accelerated the microstructure compaction. Meanwhile, during the hardening of ACP pastes, the shortest inductive period was observed in ACO ( $\sim 5 \mathrm{hrs})$; in ACMS it was somewhat longer $(\sim 6 \mathrm{hrs})$ and in ACCD remarkably longer ( $12 \mathrm{hrs})$. However, when the inductive period was over, the ACCD microstructure compaction was faster than that in ACO and ACMS. The more rapid formation of hydrates in ACCD paste was also confirmed by the higher content of HW (Fig. 3). The UWV values and their changing were slightly influenced by different $\mathrm{W} / \mathrm{S}$ and different content of A in ACP pastes (Table 3). However, it was obvious that no relationship existed between these parameters and UWV values, i.e. their influence was not essential and did not shade the peculiarities of formation of structure in pastes with different $P$.

\subsection{Strength and durability of hardened ACP pastes}

The variation of compressive strength of ACP samples kept under various conditions is given in Fig. 6. As one can see, the tendencies of change in strength of all ACP pastes with different $P$ both in moist environment and in water are of similar character, only the values of strength differ. All ACP binders are characteristic of good hydraulic properties, i.e. when put into water after hardening in moist environment, they harden further and their strength increases approaching the strength of samples hardened in moist environment. They are resistant to formation of destructive minerals (Fig. 4), and, furthermore, are insensitive to the impact of ever changing (flowing) water. The strength of samples stored in changed and unchanged water differed, but only slightly. The highest strength of samples stored under any hardening conditions was attained by ACCD, the lowest - by ACMS. Since strength is also influenced by unequal density of hardened pastes (ACO $\sim 1500 \mathrm{~kg} / \mathrm{m}^{3}$, ACMS $\sim 1420 \mathrm{~kg} / \mathrm{m}^{3}$, ACO $\left.\sim 1460 \mathrm{~kg} / \mathrm{m}^{3}\right)$, the more precise picture of effect of different $\mathrm{P}$ on strength is provided by values of estimated strength at equal density (Eq. 1). For estimation, the highest density was taken as a basic density, i.e. that of ACO paste, $1500 \mathrm{~kg} / \mathrm{m}^{3}$. The estimated strength of ACSM samples after 7 days was $\sim 20 \%$. I, n later periods of hardening, it was 3-8\% lower than that of ACO samples, while strength of ACCD samples was higher by $\sim 19 \%$ and $18-30 \%$, respectively. The results of strength tests correlated well with the results of hydration and UWV tests for ACP pastes. Namely, in ACCD paste, the processes of hydration and compaction of microstructure happened the most rapidly, while the slowest were noticed in the ACMS paste, regardless of the highest $(\mathrm{A}+\mathrm{C})$ content. The preliminary tests of freeze-thaw resistance showed that ACCD samples were also considerably more resistant to freezing and thawing than ACMS samples.

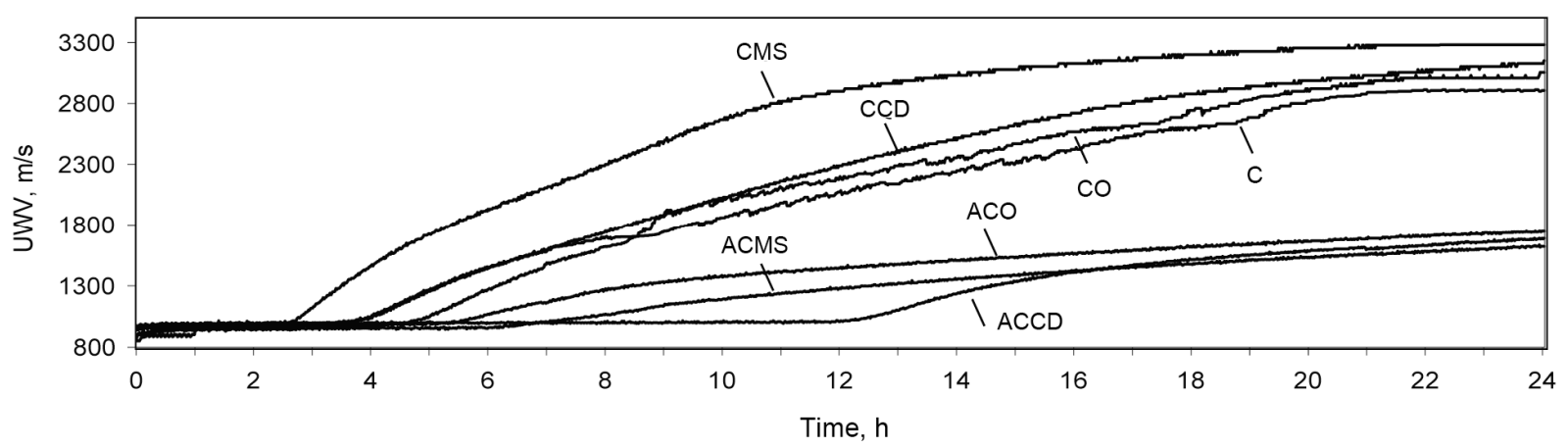

Fig. 5. The variation of UWV in C, CP and ACP pastes 


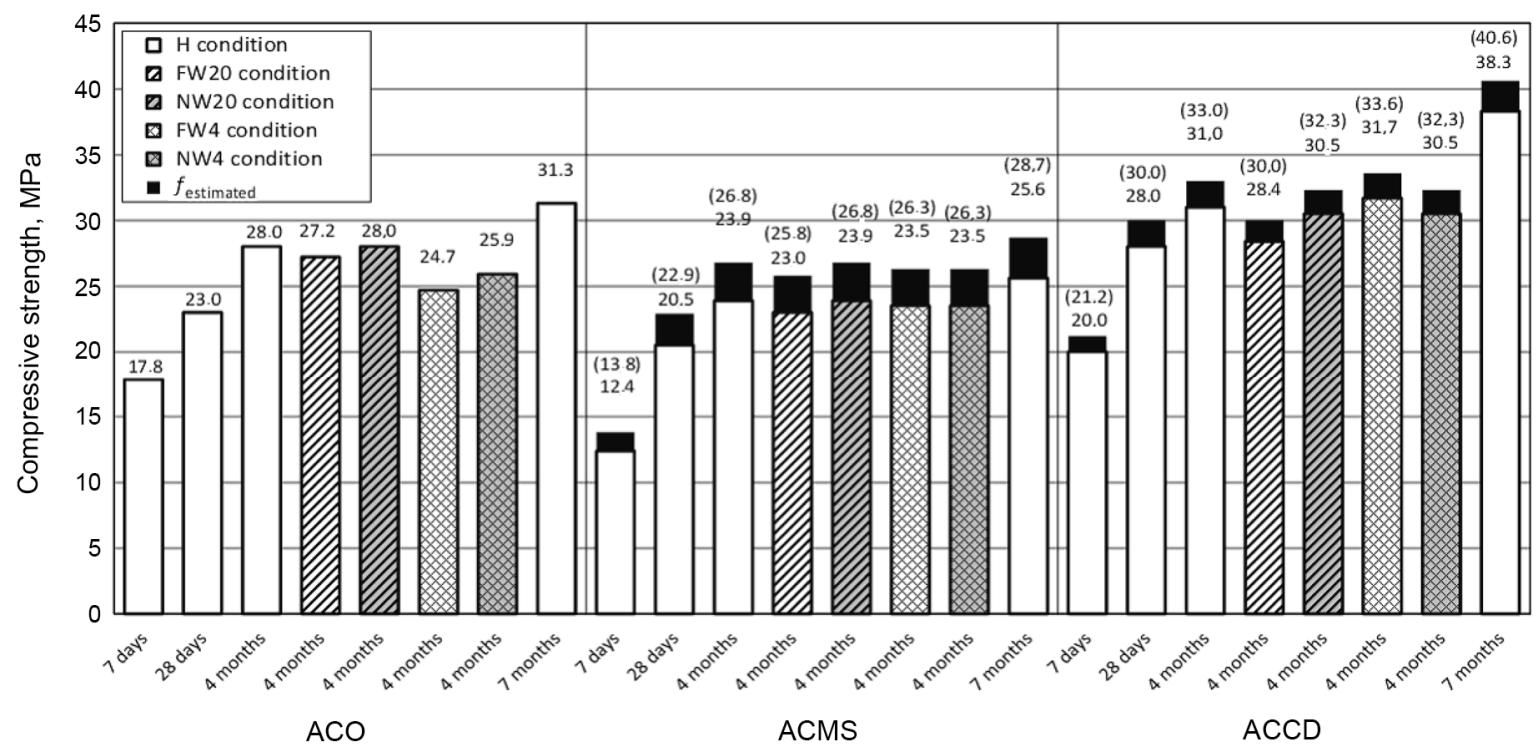

Fig. 6. The variation of actual and estimated strength (see formula 1) of ACP samples stored in various conditions

The first signs of destruction on ACSM surface appeared after 30 cycles and the loss in strength reached $20 \%$, the loss in mass was 3\%. Meanwhile, in ACCD samples, no signs of destruction were observed after 100 cycles and the loss in strength was $15 \%$, the loss in mass $0.5 \%$.

These investigations have showed that $\mathrm{P}$ impact on ACP hardening and properties was subject to all P properties, which made it impossible to predict the $\mathrm{P}$ effect on the ACP hardening process according to one property or some of them, e.g. fineness or pozzolanic activity. The structure of $\mathrm{P}$ particles, presence of admixtures and etc. could be of importance.

\section{Conclusions}

Anhydrite cement pozzolana binder (ACP), in which the main component (60-80\%) is unburned natural anhydrite, is characteristic of good durability, hydraulics and longterm hardening properties. It is resistant to impact of flowing water and formation of destructive minerals (ettringite, thaumasite). The development of hardening structure for ACP pastes is remarkably slower than that of plain or $\mathrm{P}$ modified cement pastes. $\mathrm{P}$ properties have a high effect on development of ACP structure and their effect is unlike that in cement pastes.

$\mathrm{SiO}_{2}$ compounds are found in cupola dust (CD) the high-dispersive waste from mineral wool production. They are known for high pozzolanic activity (similar to microsilica (MS)) and this waste is suitable for ACP production as a pozzolana component. ACP with $\mathrm{CD}$ is characteristic of quicker hydration, quicker structure development, as well as better durability properties in comparison to ACP with known $\mathrm{P}$, such as opoka $(\mathrm{O})$ or MS. It is likely that this is predetermined by CD chemical properties (presence of solvent compounds, alkaline reaction), as well as presence of nanoscale size particles.

Widely used $\mathrm{P}$ - microsilica - is inappropriate for ACP binder. The strength of ACMS composites are 10$30 \%$ lower than ACO or ACCD composites.

\section{References}

Alksnis, F. 1998. Tverdenie $i$ destruktsiia gipsotsementnykh kompozitsii. Leningrad. $103 \mathrm{p}$.

Andreola, F.; Barbieri, L.; Lancellotti, I.; Bignozzi, M. C.; Sandrolini, F. 2010. New blended cement from polishing and glazing ceramic sludge, International Journal of Applied Ceramic Technology 7(4): 546-555.

Bignozzi, M. C.; Bonduà, S. 2011. Alternative blended cement with ceramic residues: Corrosion resistance investigation on reinforced mortar, Cement and Concrete Research 41(9): 947-954.

http://dx.doi.org/10.1016/j.cemconres.2011.05.001

Bignozzi, M. C.; Saccani, A.; Sandrolini, F. 2009. Matt waste from glass separated collection: An eco-sustainable addition for new building materials, Waste Management 29(1): 329334. http://dx.doi.org/10.1016/j.wasman.2008.02.028

Bignozzi, M. C.; Saccani, A.; Sandrolini, F. 2010. Chemicalphysical behaviour of matt waste in cement mixtures, Construction and Building Materials 24(11): 2194-2199. http://dx.doi.org/10.1016/j.conbuildmat.2010.04.038

Boudchicha, A.; Zouaoui, M. C.; Gallias, J-L.; Mezghiche, B. 2007. Analysis of the effects of mineral admixtures on the strength of mortars: Application of the predictive model of Feret, Journal of Civil Engineering and Management 13(2): 87-96.

Colak, A. 2002. The long-term durability performance of gypsum-Portland cement-natural pozzolana blends, Cement and Concrete Research 32(1): 109-115. http://dx.doi.org/10.1016/S0008-8846(01)00637-8

EN 197-1:2011 Cement - Part 1: Composition, specification and conformity criteria for common cements. Brussels. $38 \mathrm{p}$.

Grigelis, A.; Kadunas, V. 1994. Lietuvos geologija [The Geology of Lithuania]. Vilnius: Institute of Geology. 447 p.

Kadri, E. H.; Aggoun, S.; De Schutter, G.; Ezziane, K. 2010. Combined effect of chemical nature and fineness of mineral powder on portland cement hydration, Materials and Structures 43(5): 665-673.

http://dx.doi.org/10.1617/s11527-009-9519-6

Kamada, T.; Uschida, S.; Rokugo, K. 2005. Nondestructive evaluation of setting and hardening of cement paste based 
on ultrasonic propagation characteristics, Journal of Advanced Concrete Technology 3(3): 343-353.

http://dx.doi.org/10.3151/jact.3.343

Korpa, A.; Kowald, T.; Trettin, R. 2008. Hydration behaviour, structure and morphology of hydration phases in advanced cement-based systems containing micro and nanoscale pozzolanic additives, Cement and Concrete Research 38(7): 955-962.

http://dx.doi.org/10.1016/j.cemconres.2008.02.010

Lasys, A.; Kadunas, V. 1994. Lithuanian anhydrite and its utilisation, International Cement Review, November, 39-40.

Leškevičienè, V.; Nizevičienè, D. 2010. Anhydrite binder calcined from phosphogypsum, Ceramics-Silikaty 54(2): 152-159.

Lin, K. L.; Lin, D. F. 2006. Hydration characteristics of municipal solid waste incinerator bottom ash slag as a pozzolanic material for use in cement, Cement and Concrete Composites 28(9): 817-823.

http://dx.doi.org/10.1016/j.cemconcomp.2006.03.003

Liu, Z.; Zhang, Y.; Jiang, Q.; Sun, G.; Zhang, W. 2011. In situ continuously monitoring the early age microstructure evolution of cementitious materials using ultrasonic measurement, Construction and Building Materials 25(10): 3998-4005.

http://dx.doi.org/10.1016/j.conbuildmat.2011.04.034

Martinez-Aguilar, O. A.; Castro-Borges, P.; Escalante-García, J. I. 2010. Hydraulic binders of Fluorgypsum-Portland cement and blast furnace slag, stability and mechanical properties, Construction and Building Materials 24(5): 631-639. http://dx.doi.org/10.1016/j.conbuildmat.2009.11.006

Oliveira, L. A. P; Gomes, J. P. C.; Pereira, C. N. G. 2006. Study of sorptivity of self-compacting concrete with mineral additives, Journal of Civil Engineering and Management 12(3): 215-220.

Qing, Y.; Zenan, Z.; Deyu, K.; Rongshen, C. 2007. Influence of nano- $\mathrm{SiO}_{2}$ addition on properties of hardened cement paste as compared with silica fume, Construction and Building Materials 21(3): 539-545.

http://dx.doi.org/10.1016/j.conbuildmat.2005.09.001

Reinhardt, H. V.; Grosse, C. U. 2004. Continuous monitoring of setting and hardening of mortar and concrete, Construction and Building Materials 18(3): 145-154. http://dx.doi.org/10.1016/j.conbuildmat.2003.10.002

Saccani, A.; Sandrolini, F.; Andreola, F.; Barbieri. L.; Corradi, A.; Lancellotti, I. 2005. Influence of the pozzolanic fraction obtained from vitrified bottom-ashes from MSWI on the properties of cementitious composites, Materials and Structures 38(3): 367-371.

http://dx.doi.org/10.1007/BF02479303

Sattler, H. 1997. The importance of porosity for the properties of hardened gypsum plaster products, $Z K G$ International 1: 54-62.
Senff, L.; Labrincha, J. A.; Fereira, V. M.; Hotza, D.; Repette, W. L. 2009. Effect of nano-silica on rheology and fresh properties of cement pastes and mortars, Construction and Buildings Materials 23(7): 2487-2491.

http://dx.doi.org/10.1016/j.conbuildmat.2009.02.005

Shi, C.; Wu, Y.; Shao, C.; Reflier, C.; Wang, H. 2005. Characteristics and pozzolanic reactivity of glass powders, $\mathrm{Ce}$ ment and Concrete Research 35(5): 987-983. http://dx.doi.org/10.1016/j.cemconres.2004.05.015

Singh, M.; Garg, M. 1996. Relationship between mechanical properties and porosity of water-resistant gypsum binder, Cement and Concrete Research 26(3): 449-456. http://dx.doi.org/10.1016/S0008-8846(96)85032-0

Subramanian, K. V.; Wang, X. 2010. An investigation of microstructure evolution in cement paste through setting using ultrasonic and rheological measurements, Cement and Concrete Research 40(1): 33-44. http://dx.doi.org/10.1016/j.cemconres.2009.09.018

Tokarev, Y.; Yakovlev, G. 2010. Activation of hardening anhydrite compositions with superdispersed agents, in Proc. of the $10^{\text {th }}$ International Conference "Modern Building Materials, Structure and Techniques”, 19-22 May, 2010, Vilnius, Lithuania. Selected papers, 295-299.

Trtnik, G.; Turk, G.; Kavčič, F.; Bokan Bosilkjkov, V. 2008. Possibilities of using the ultrasonic wave transmission method to estimate initial setting time of cement paste, Cement and Concrete Research 38(11): 1336-1342. http://dx.doi.org/10.1016/j.cemconres.2008.08.003

Yan, P.; Yang, W.; Qin, X.; You, Y. 1999. Microstructure and properties of the binder of fly ash-fluorogypsum-Portland cement, Cement and Concrete Research 29(3): 349-354. http://dx.doi.org/10.1016/S0008-8846(98)00214-2

Volzhenskii, A.; Stambulko, V.; Ferronskaia, A. 1971. Gipsotsementno-putstsolanovoe viazhushchee, betony i izdeliia. Moskva. 316 p.

Žvironaitè, J.; Kizinevič, V. 2010. Researches of possibility of application of Lithuanian anhydrite, in Proc. of the $10^{\text {th }}$ International Conference "Modern Building Materials, Structure and Techniques", 19-22 May, 2010, Vilnius, Lithuania. Selected papers, 346-350.

Žvironaite, J.; Kerienė, J.; Makutenienè, D.; Kizinevič, V. 2010. The peculiarities of hardening of composite anhydrite cement pozzolanna binding material with not burned natural anhydrite, Materials Science (Medžiagotyra) 16(2): 159-164.

Žvironaitè, J.; Pundienè, I.; Antonovič, V.; Balkevičius, V. 2011. Investigation of peculiarities in the hardening process of portland cements with active additives out of waste, Material science (Medžiagotyra) 17(1): 73-79.

Jadvyga ŽVIRONAITÉ. Assoc. Prof. Dr at the Laboratory of Building Materials of Scientific Institute of Thermal Insulation of Vilnius Gediminas Technical University, Linkmenų g. 28, LT-08217 Vilnius, Lithuania. Research interests: materials science, building materials properties, inorganic binding materials, gypsum and gypsum based products.

Ina PUNDIENE். Dr at the Laboratory of Building Products Technology of Scientific Institute of Thermal Insulation of Vilnius Gediminas Technical University, Linkmenu g. 28, LT-08217 Vilnius, Lithuania. Research interests: refractory constables, materials science, building materials properties, binding materials.

Sergejus GAIDUČIS. Assoc. Prof. Dr at the Department of Labour Safety and Fire Protection Vilnius Gediminas Technical University, Sauletekio al. 11, LT-10223 Vilnius, Lithuania. Research interests: waste recycling, environments protection, materials science, binding materials composite, building materials properties.

Viktor KIZINIEVIČ. Dr at the Laboratory of Building Materials of Scientific Institute of Thermal Insulation of Vilnius Gediminas Technical University, Linkmenu g. 28, LT-08217 Vilnius, Lithuania. Research interests: materials science, building materials properties, frost resistance, ceramics materials, experimental design. 